\title{
Use of buffer methods to estimate the potential acidity of Mato Grosso soils
}

\section{Uso de métodos tampões para estimar a acidez potencial de solos de Mato Grosso}

\author{
Marcelo Ribeiro Vilela Prado ${ }^{(1 D}$, Milton Ferreira de Moraes $^{2}$ (D) , Fabrício Tomaz Ramos ${ }^{3 *}$ (D), \\ Carlos Leandro Rodrigues do Santos ${ }^{2}$ (D) David Vilas Boas de Campos ${ }^{4}(\mathbb{D})$, Gisele Teixeira Barros ${ }^{4}$ (iD)
}

\author{
1 Universidade Federal de Mato Grosso/UFMT, Cuiabá, MT, Brasil \\ 2Universidade Federal de Mato Grosso/UFMT, Barra do Garças, MT, Brasil \\ ${ }^{3}$ Empresa Matogrossense de Pesquisa, Assistência e Extensão Rural/EMPAER, Cuiabá, MT, Brasil \\ ${ }^{4}$ Empresa Brasileira de Pesquisa Agropecuária/Embrapa, Embrapa Solos, Rio de Janeiro, RJ, Brasil \\ ${ }^{*}$ Corresponding author: fabriciotomazramos@gmail.com \\ Received in October 30, 2019 and approved in February 27, 2020
}

\begin{abstract}
Mato Grosso, with a total area of $903357 \mathrm{~km}^{2}$, does not have an official methodology for estimating soil potential acidity $(\mathrm{H}+\mathrm{Al})$, and determination of $\mathrm{H}+\mathrm{Al}$ using the standard method is onerous and time consuming. The objective of this study was to compare estimated values of $\mathrm{H}+\mathrm{Al}$ determined using the standard calcium acetate method with those obtained using three buffer methods, namely, the Shoemaker, McLean, and Pratt (SMP) buffer, Sikora buffer, and Santa Maria buffer (SMB) methods, with samples of the main classes of cultivated soils in the state of Mato Grosso. A total of 196 soil samples were collected from the arable layer $(0-20 \mathrm{~cm})$ in agropastoral and adjacent native systems. Statistical models were obtained and compared with models used by laboratories that are hypothetically inadequate because there is no calibration for soils in the state. After laboratory analyses, the paired $\mathrm{H}+\mathrm{Al}$ and equilibrium $\mathrm{pH}$ values corresponding to the equilibrium of each buffer solution (SMP buffer, SMB, and Sikora buffer) were subjected to nonlinear regression analysis $(P<0.05)$. The SMB method, which does not release pollutant residues into the environment, was better than the Sikora and SMP

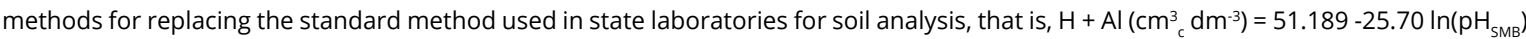
$\left(R^{2}=0.88, P<0.0001\right)$. Thus, if laboratories use uncalibrated equations to estimate soil potential acidity, the recommended limestone correction will be underestimated or overestimated, which may compromise crop productivity in Mato Grosso.
\end{abstract}

Index terms: Limestone; SMP buffer; Sikora buffer; Santa Maria buffer.

\begin{abstract}
RESUMO
O estado de Mato Grosso, com uma área de 903357 km², não possui uma metodologia oficial para estimar a acidez potencial do solo $(\mathrm{H}+\mathrm{Al})$, e sua determinação pelo método padrão é onerosa e demorada. O objetivo deste estudo foi comparar os valores estimados de $(\mathrm{H}+\mathrm{Al})$ determinados pelo método padrão de acetato de cálcio com os obtidos por três métodos tampão, a saber, tampão Shoemaker, McLean and Pratt (SMP), tampão Sikora e tampão Santa Maria (SMB), considerando amostras das principais classes de solos cultivados no estado de Mato Grosso. Para isso, 196 amostras de solo foram coletadas na camada arável $(0-20 \mathrm{~cm})$ em diferentes sistemas agropastoris e nativos adjacentes. Os modelos estatísticos obtidos foram comparados com modelos hipoteticamente inadequados utilizados pelos laboratórios, pois não há calibração para solos no estado. Após as análises laboratoriais, os pares de valores determinados de $\mathrm{H}+\mathrm{Al}$ e o pH de equilíbrio corresponde de cada solução tampão foram submetidos a análise de correlação e regressão não-linear $(p<0,05)$. Verificouse que o método SMB, que não gera resíduos de poluentes no meio ambiente, foi melhor que os métodos Sikora e SMP para substituir o método padrão, usando a equação $\mathrm{H}+\mathrm{Al}(\mathrm{cm} 3 \mathrm{c} \mathrm{dm}-3)=51.189-25.70 \ln (\mathrm{pHSMB})\left(\mathrm{R}^{2}=0,88, \mathrm{P}<0,0001\right)$. Assim, se os laboratórios usarem equações não calibradas para estimar a acidez potencial do solo, isso implica subestimar ou superestimar a recomendação de calcário, o que pode comprometer a produtividade das culturas no Mato Grosso.
\end{abstract}

Termos para indexação: Calcário; tampão SMP; tampão Sikora; tampão Santa Maria.

\section{INTRODUCTION}

In Brazil, base saturation (V\%) is the method most commonly used to estimate the amount of limestone needed to correct soil $\mathrm{pH}$ for agricultural purposes. This estimation requires precise quantification of potential acidity $(\mathrm{H}+\mathrm{Al})$, which is normally performed using the standard method of $0.5 \mathrm{~mol} \mathrm{~L}^{-1}$ calcium acetate buffered to $\mathrm{pH} 7.0$ (Teixeira et al., 2017). However, this is a time-consuming and expensive routine procedure performed in soil analysis laboratories (Quaggio; Van Raij; Malavolta, 1985; Santanna et al., 2011; Almeida Júnior et al., 2015). Therefore, several studies in 
Brazil have sought to estimate the levels of $\mathrm{H}+\mathrm{Al}$ using the method developed by Shoemaker, McLean, and Pratt (SMP) (Shoemaker; Mclean; Pratt, 1961). Numerous authors have developed regression equations to estimate the $\mathrm{H}+\mathrm{Al}$ values in some Brazilian states and concluded that the SMP method is easy to perform and produces estimates showing an excellent correlation with the $\mathrm{H}+\mathrm{Al}$ content extracted using the calcium acetate method (Almeida Júnior et al., 2015; Araújo et al., 2014; Escosteguy; Bissani, 1999; Gama et al., 2013; Maeda et al., 1997; Moreira et al., 2004; Pavan; Oliveira; Miyazawa, 1996; Santanna et al., 2011; Sousa et al., 1989; Steiner et al., 2009).

Despite its advantages, the SMP method has been questioned because of the toxic reagents used in it. Therefore, studies were carried out to improve the method by replacing these reagents with other nontoxic substances (Sikora, 2006; Toledo et al., 2012), and modified buffer methods involving Sikora and Santa Maria buffer (SMB) were developed. In addition, studies on these buffer methods have emphasized that calibration of the corresponding equations must be regionally based because of the variation in soil chemical, physical, and mineralogical characteristics among regions (Quaggio; Van Raij; Malavolta, 1985; Pereira et al., 1998).

The state of Mato Grosso, in Brazil, has an area of $903357 \mathrm{~km}^{2}$ and does not have an official method for reliably estimating the $\mathrm{H}+\mathrm{Al}$ content using buffer solutions. Hypothetically, the use of equations developed for other Brazilian states on soils from Mato Grosso could lead to inadequate soil corrective recommendations, especially because of the size of cultivated areas and diversity of soils in the state (Maia et al., 2009; Moreira; Vasconcelos, 2007). Therefore, the objective of this study was to estimate the soil values of $\mathrm{H}+\mathrm{Al}$ using three different buffer methods, namely, the SMP, Sikora, and SMB methods, and to compare these estimates with values determined using the standard calcium acetate method.

\section{MATERIAL AND METHODS}

\section{Sample collection}

The regional climate of Mato Grosso, Brazil, is Aw according to the Köppen-Geiger classification, with a rainy period from October to April and a dry period from May to September (Alvares et al., 2013). We used the main classes of soils cultivated in the state of Mato Grosso, Brazil, between January and December 2017, with the aim of obtaining variation in clay, organic matter, aluminium, and exchangeable bases, as recommended by Quaggio, Van Raij and Malavolta (1985). For this purpose, available maps of the biomes and soils of Mato Grosso (Maia et al., 2009; Moreira; Vasconcelos, 2007) were overlaid. Then, according to soil profiles described by the RADAMBRASIL Project and the Socioeconomic and Ecological Diagnostic Project of the State Secretariat of Planning and Management of Mato Grosso (Moreira; Vasconcelos, 2007), sampling points were selected as shown in Figure 1B.

Forty-nine soil types (Latosols, Argisols, Neosols, Cambisols, Gleysols, and Plinthosols, according to Santos et al., 2013) were sampled under native vegetation in Mato Grosso (Figure 1B) as well as in surrounding (up to 200 m away) cultivated areas with pasture, soybean, corn, and cotton under different management systems and years of cultivation. This generated a total of 196 sampling areas. In the areas surrounding the selected soil profile locations and in the native forest and adjacent agropastoral systems, non-intact soil samples were collected from the topsoil layer $(0-0.20 \mathrm{~m})$, which is the layer to which limestone is commonly applied and incorporated. In each environment, five individual samples of $2 \mathrm{~L}$ were collected to form a composite sample of $10 \mathrm{~kg}$.

\section{Laboratory analysis}

Soil texture was determined using the pipette method (Teixeira et al., 2017). The chemical analyses performed included the determination of $\mathrm{pH}$ in water and $\mathrm{CaCl}_{2}$ in a 1:2.5 K:P ratio. The mineral nutrients were first extracted using Mehlich-1 solution and subsequently determined by flame photometry and spectrocolorimetry (Model SpectrA A-10; Varian, France); $\mathrm{Ca}, \mathrm{Mg}$, and $\mathrm{Al}$ were extracted with $1.0 \mathrm{~mol} \mathrm{~L}^{-1} \mathrm{KCl}$. Then, $\mathrm{Ca}$ and $\mathrm{Mg}$ were quantified by complexometric titration with ethylenediamine tetraacetic acid (EDTA), and Al was determined by titration with acid/ base neutralization. Soil organic matter was digested with potassium dichromate and determined by Walkley-Black titration. $\mathrm{Zn}, \mathrm{Mn}, \mathrm{Cu}$, and Fe were extracted with Mehlich-1 solution, and their levels were determined by inductively coupled plasma optical emission spectroscopy (ICP-OES, Optima $^{\text {TM }} 8300$ ICP-OES Analyzer; USA), while B was extracted in hot water and $\mathrm{S}$ with monobasic calcium phosphate. Soil potential acidity $(\mathrm{H}+\mathrm{Al})$ was determined using the standard method with calcium acetate buffered to $\mathrm{pH} 7.0$ and by volumetric determination with $\mathrm{NaOH}$ solution in the presence of phenolphthalein as an indicator (Teixeira et al., 2017). Estimates of $\mathrm{H}+\mathrm{Al}$ were obtained with different buffer solutions using the SMP (Santanna et al., 2011; Shoemaker; Mclean; Pratt, 1961), Sikora (Sikora, 2006), and SMB methods (Toledo et al., 2012). The soil: $\mathrm{CaCl}_{2}$ :buffer ratios were 10:25:5 for the SMP and SMB methods and 10:25:10 for the Sikora method. 


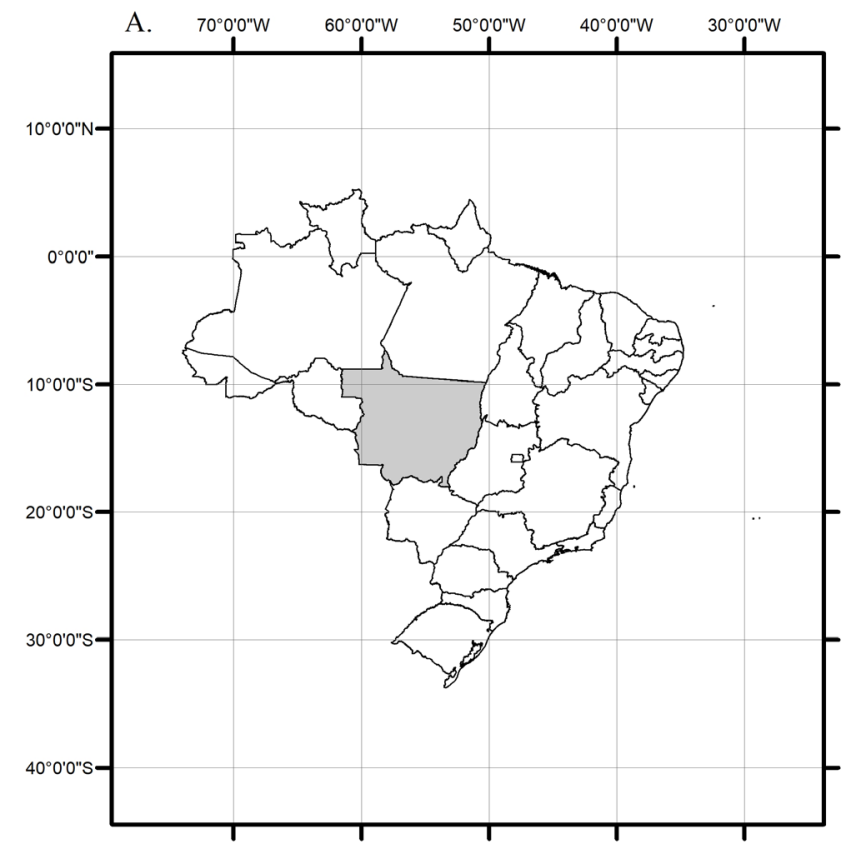

B.

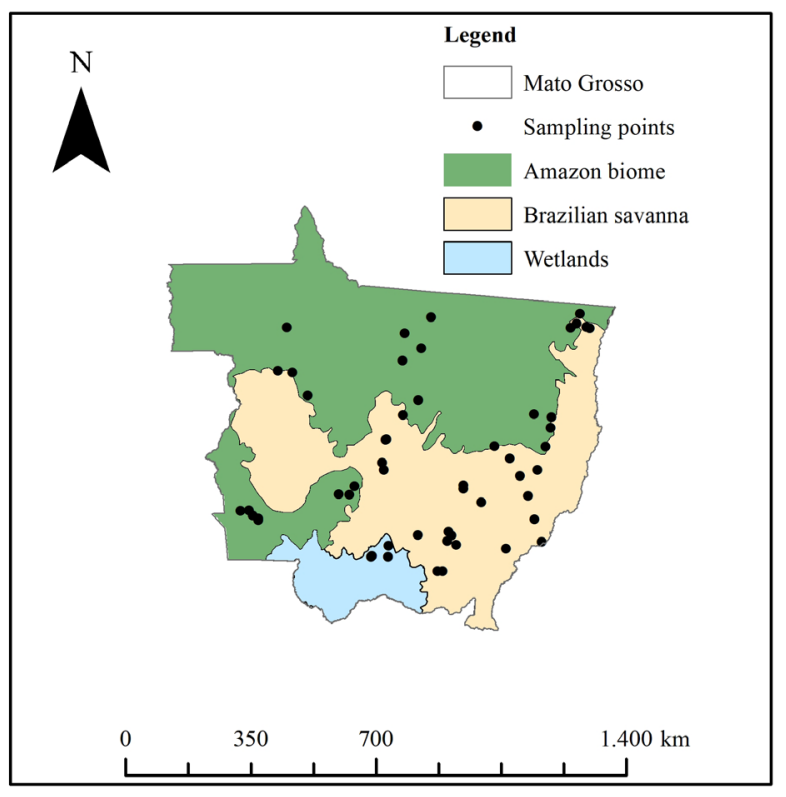

Figure 1: (A) Map of Brazil with cross-hatching of the state of Mato Grosso (MT); (B) illustration of collection points throughout the territory and biomes of MT.

The sum of bases (SB), cation exchange capacity (CEC), aluminium saturation $(\mathrm{m})$, and base saturation $(\mathrm{V} \%)$ were calculated based on the values of exchangeable cations and $\mathrm{H}+\mathrm{Al}$ (Quaggio; Van Raij; Malavolta, 1985).

\section{Statistical analysis}

Paired data for the $\mathrm{H}+\mathrm{Al}$ content obtained by standard extraction and the $\mathrm{pH}$ values obtained using the SMP, Sikora, and SMB methods were subjected to analysis of variance and Fisher's test $(\alpha=0.05)$. The paired data were then adjusted by means of nonlinear regression according to the logarithmic model $[\mathrm{y}=\mathrm{y} 0$ $+a \cdot \ln (\mathrm{x})]$, where $\mathrm{y} 0$ and a are estimated coefficients. The accuracy of these adjustments was evaluated using the significance of coefficients $a$ and $b$ by means of Pearson correlation ( $\mathrm{r}$ ) and regression determination $\left(\mathrm{R}^{2}\right)$ coefficients (Larson; Farber, 2010). The data were analysed using SigmaPlot version 12.5 statistical software. Additionally, we compared the equation obtained in this study with the main equations currently used in Brazil to estimate point acidity. We then compared our equation with "uncalibrated" equations, which soil laboratories in Mato Grosso have been employing in combination with the base saturation method to develop limestone addition recommendations.

\section{RESULTS AND DISCUSSION}

The physical and chemical attributes of the 196 surface-layer samples of the 49 soil types and the 147 samples from adjacent cultivated areas with soybean, corn, pasture, and cotton under different management systems and years of cultivation are presented in Table 1. Variation in the soil attributes was expected because the soil samples were collected from cultivated areas that were subjected to acidity correction management and from native areas that had never received limestone application. This variation in data pairs, according to Quaggio, Van Raij and Malavolta (1983), is important for obtaining the reported calibration curves of buffer $\mathrm{pH}$ and potential acidity, which will be discussed later.

The results summarized in Table 1 are in agreement with those reported by Ramos et al. (2018), as shown by the fact that the correlation detected in the present study between CEC and clay content (Pearson's $\mathrm{r}=0.37, \mathrm{P}<$ $0.000 ; n=196)$ was mainly driven by the variation in organic matter content (Pearson's $\mathrm{r}=0.76, \mathrm{P}<0.0001, \mathrm{n}$ =196). In contrast, the increase in $\mathrm{H}+\mathrm{Al}$ content resulted in a decrease in buffer $\mathrm{pH}$ (Figure 2), which is consistent with the findings of previous studies (Almeida Júnior et al., 2015; Maeda et al., 1997; Quaggio; Van Raij; Malavolta, 1985; Toledo et al., 2012). 
Table 1: Descriptive statistics of the chemical and physical attributes of 196 soil samples collected from the $0-0.20 \mathrm{~m}$ soil layer in the state of Mato Grosso.

\begin{tabular}{|c|c|c|c|c|c|}
\hline \multirow{2}{*}{ Attribute } & \multicolumn{2}{|c|}{ Value } & \multirow{2}{*}{ Average } & \multirow{2}{*}{$\begin{array}{l}\text { Standard } \\
\text { deviation }\end{array}$} & \multirow{2}{*}{$\mathrm{CV}(\%)^{\dagger}$} \\
\hline & Minimum & Maximum & & & \\
\hline & \multicolumn{5}{|c|}{---------------------------------- Dimensionless ----------------------------------- } \\
\hline $\mathrm{pH} \mathrm{H} \mathrm{H}_{2} \mathrm{O}$ & 4.20 & 8.00 & 5.60 & 0.67 & 12 \\
\hline $\mathrm{pHCaCl}{ }_{2}$ & 3.40 & 7.08 & 4.75 & 0.64 & 13 \\
\hline $\mathrm{pH}$ SMP & 5.02 & 7.38 & 6.27 & 0.43 & 7 \\
\hline $\mathrm{pH} S M B$ & 4.95 & 7.35 & 6.18 & 0.44 & 7 \\
\hline pH Sikora & 5.63 & 7.41 & 6.64 & 0.32 & 5 \\
\hline $\mathrm{H}+\mathrm{Al}^{(1)}$ & 0.30 & 12.00 & 4.50 & 2.00 & 44 \\
\hline $\mathrm{Al}^{3+(2)}$ & 0.00 & 2.60 & 0.30 & 0.50 & 173 \\
\hline $\mathrm{Ca}^{2+(3)}$ & 0.10 & 11.70 & 2.00 & 1.70 & 84 \\
\hline $\mathrm{Mg}^{2+(4)}$ & 0.10 & 4.60 & 0.90 & 0.70 & 74 \\
\hline $\mathrm{K}^{+(5)}$ & 0.10 & 2.80 & 0.20 & 0.20 & 124 \\
\hline $\mathrm{SB}^{(6)}$ & 0.10 & 12.60 & 3.10 & 2.30 & 73 \\
\hline $\mathrm{CTC}^{(7)}$ & 2.80 & 21.10 & 7.60 & 3.00 & 40 \\
\hline$V^{(8)}$ & 2.70 & 94.80 & 39.20 & 20.20 & 52 \\
\hline $\mathrm{OC}^{(9)}$ & 3.10 & 29.40 & 10.40 & 5.00 & 48 \\
\hline $\mathrm{SOM}^{(10)}$ & 5.30 & 50.70 & 17.90 & 8.60 & 48 \\
\hline Sand & 100.00 & 900.00 & 581.10 & 200.70 & 35 \\
\hline Silt & 25.00 & 325.00 & 77.60 & 57.30 & 74 \\
\hline Clay & 75.00 & 700.00 & 341.30 & 168.50 & 49 \\
\hline
\end{tabular}

(1) H+Al - potential acidity; (2) Al3+ - aluminium; (3) Ca2+ - calcium; (4) Mg2+ - magnesium; (5) K+ - potassium; (6) SB - sum of bases; (7) CEC - cation exchange capacity; (8) V - saturation by bases; (9) $\mathrm{m}$ - saturation by aluminium; (9) CO - organic carbon; (10) SOM - soil organic matter; † CV - coefficient of variation.

The logarithmic model best explained the relationship between independent ( $\mathrm{pH}$ buffer: SMB $\mathrm{pH}$, Sikora $\mathrm{pH}$, and SMP $\mathrm{pH}$ ) and dependent (potential acidity: $\mathrm{H}+\mathrm{Al}$ ) variables (Figure 2 ). This model also fit the soils of the states of São Paulo (Quaggio; Van Raij; Malavolta, 1985), Minas Gerais (Gama et al., 2013), Goiás (Sousa et al., 1989), Mato Grosso do Sul Maeda et al. (1997), and Rio de Janeiro (Pereira et al., 1998). However, it is important to note that the soil organic matter content in the present study ranged from 5 to 50.7 $\mathrm{g} \mathrm{kg}^{-1}$, which is a lower and narrower range than that in other regions (10-300 $\left.\mathrm{g} \mathrm{kg}^{-1}\right)$, although the clay content remained within a similar range (75-700 $\mathrm{g} \mathrm{kg}^{-1}$ ) (Quaggio;
Van Raij; Malavolta, 1985). We found that both buffer $\mathrm{pH}$ methods presented higher data dispersion for $\mathrm{H}+\mathrm{Al}$ contents greater than $6 \mathrm{cmol}_{\mathrm{c}} \mathrm{dm}^{-3}$, indicating possible inefficiency in extracting $\mathrm{H}+\mathrm{Al}$ from the more highly buffered acidic soils (Figure 2). When Silva, Costa and Farnezi (2006) studied the soils in the Jequitinhonha Valley (Minas Gerais), they also observed greater dispersion of $\mathrm{H}+\mathrm{Al}$ contents above $8 \mathrm{cmol}_{\mathrm{c}} \mathrm{dm}^{-3}$.

In the present study, a comparison of curve fits based on the angular coefficient revealed that the Sikora method (37.47 \pm 0.925 std. error via $t$ test; $\mathrm{P}<0.0001)$ overestimated potential acidity values compared with those obtained with the SMB $(25.60 \pm 0.6859$ std. error 
via $t$ test; $\mathrm{P}<0.0001)$ and SMP $(26.54 \pm 0.616$ std. error via $t$ test; $\mathrm{P}<0.0001)$ methods, which were statistically similar. This discrepancy in relation to the Sikora method can be explained by the fact that the method was developed for American soils $(\mathrm{pH}>5.3)$, which are less acidic than tropical soils (Santana et al., 2011; Toledo et al., 2012). These results were in agreement with those described by Santana et al. (2011) and Toledo (2012), who concluded that the Sikora method is not efficient enough in estimating $\mathrm{H}+\mathrm{Al}$, as it tends to overestimate the $\mathrm{H}+\mathrm{Al}$ values relative to those obtained with the SMP method.

Although the SMP method was the best in estimating potential acidity (coefficient of determination closer to 1.00), further studies are recommended, such as the incubation of soil samples with doses of carbonate calcium, because calcium acetate may decrease the efficiency in extracting $\mathrm{H}+\mathrm{Al}$ from more-buffered soils (Predebon et al., 2018). In addition, further research should employ different concentrations of buffer solution when examining more-buffered soils to reduce data dispersion at high $\mathrm{cmol}_{\mathrm{c}} \mathrm{dm}^{-3}$ values (Figure 2), as observed for Organosols (Silva et al., 2008).

Problematic results may be obtained if laboratories use uncalibrated equations to estimate potential acidity for
Mato Grosso soils. For example, when estimating potential acidity for a buffer $\mathrm{pH}$ value $=5.0$ (SMP buffer) $($ Table 2$)$, higher values of $\mathrm{H}+\mathrm{Al}$ were obtained by the equations of (Gama et al., 2013), Maeda et al. (1997), Quaggio, Van Raij and Malavolta, (1985), and Sousa et al. (1989) when compared with the general equation used in the present study, that is, $y=53.105-26.54 \ln (\mathrm{pH}$ SMP).

In relation to the estimates reported herein, when using the equations of Araújo (2014), (Gama et al., 2013), Maeda et al. (1997), Pavan, Oliveira and Miyazawa, (1996), Quaggio, Van Raij and Malavolta, (1985), and Sousa et al. (1989), the $\mathrm{H}+\mathrm{Al}$ content was overestimated for more acidic soils $(\mathrm{pH} \leq 5.0)$; conversely, it was underestimated for soils with an SMP pH higher than 5.0. In contrast, the equation of Maeda et al. (1997) overestimated the values up to $\mathrm{pH}_{\mathrm{SMP}}=6.0$. It should be noted that in comparison with the equations of Quaggio, Van Raij and Malavolta, (1985), which are widely used in Brazil, and Sousa et al. (1989), which is recommended for the Cerrado region (a biome that covers a part of Mato Grosso, Figure 1), the equations obtained in this study estimated higher $\mathrm{H}+\mathrm{Al}$ values for soils with a $\mathrm{pH}_{\mathrm{SMP}}$ above 5.4, a generally more common condition for soils under cultivation in the state of Mato Grosso and central Brazil (Table 2).

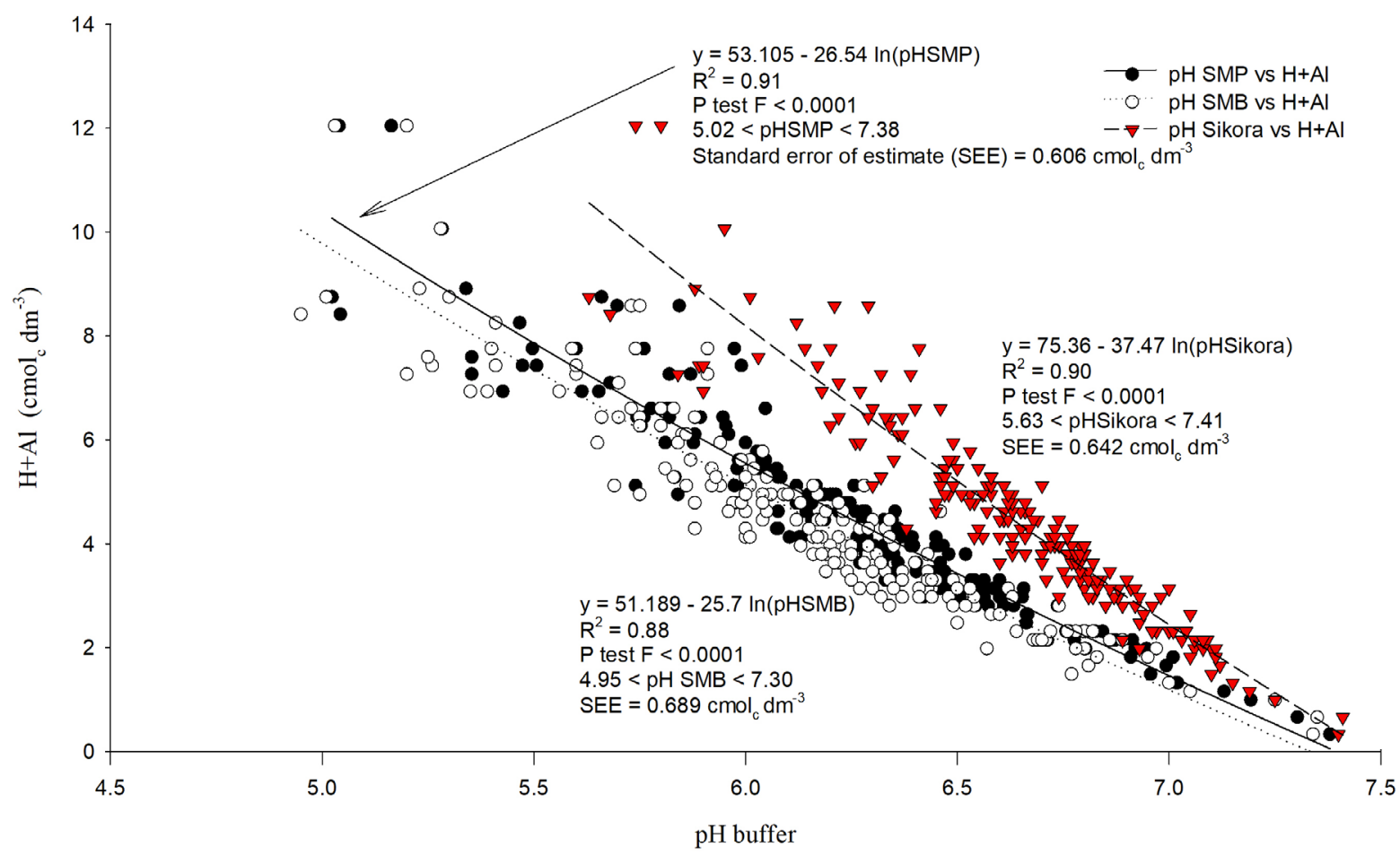

Figure 2: Nonlinear regression between the paired values of $\mathrm{H}+\mathrm{Al}$ determined using the calcium acetate method and SMB pH, Sikora $\mathrm{pH}$, and SMP pH. 
Table 2: Values of potential acidity $(\mathrm{H}+\mathrm{Al})$ estimated in Mato Grosso and other states of Brazil.

\begin{tabular}{|c|c|c|c|c|c|c|c|c|}
\hline \multirow{2}{*}{ Source } & \multirow{2}{*}{ State } & \multirow{2}{*}{ Equation } & \multicolumn{6}{|c|}{ pH SMPt† } \\
\hline & & & 4.5 & 5.0 & 5.5 & 6.0 & 6.5 & 7.0 \\
\hline & & & \multicolumn{6}{|c|}{ 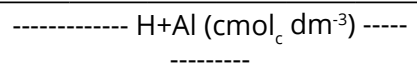 } \\
\hline Quaggio, Van Raij and Malavolta, (1985) & SP & $\ln (\mathrm{H}+\mathrm{Al})=7.76-1.053 \mathrm{pHSMP}$ & 20.5 & 12.1 & 7.2 & 4.2 & 2.5 & 1.5 \\
\hline Gama et al. (2013) & MG & $\ln (\mathrm{H}+\mathrm{Al})=8.06-1.111 \mathrm{pHSMP}$ & 21.3 & 12.2 & 7.0 & 4.0 & 2.3 & 1.3 \\
\hline Sousa et al. (1989) & GO & $\ln (\mathrm{H}+\mathrm{Al})=7.719-1.068 \mathrm{pHSMP}$ & 18.4 & 10.8 & 6.3 & 3.7 & 2.2 & 1.3 \\
\hline Pavan, Oliveira and Miyazawa, (1996) & PR & $\ln (\mathrm{H}+\mathrm{Al})=6.0687-0.744 \mathrm{pHSMP}$ & 15.2 & 10.5 & 7.2 & 5.0 & 3.4 & 2.4 \\
\hline Maeda et al. (1997) & MS & $\ln (\mathrm{H}+\mathrm{Al})=8.086-1.062 \mathrm{pHSMP}$ & 27.3 & 16.1 & 9.4 & 5.6 & 3.3 & 1.9 \\
\hline Escosteguy and Bissani (1999) & $\mathrm{RS} / \mathrm{SC}$ & $\log (\mathrm{H}+\mathrm{Al})=3.914-0.391$ pHSMP & 13.9 & 8.8 & 5.6 & 3.6 & 2.3 & 1.5 \\
\hline Moline et al. (2011) & RO & $\mathrm{H}+\mathrm{Al}=31.22-8.20 \mathrm{pHSMP}+0.59 \mathrm{pHSMP}{ }^{2}$ & 6.3 & 5.0 & 4.0 & 3.3 & 2.8 & 2.7 \\
\hline Gama et al. (2013) & PA & $\mathrm{H}+\mathrm{Al}=77.77+20.61 \mathrm{pHSMP}-1.435 \mathrm{pHSMP}{ }^{2}$ & 14.1 & 10.6 & 7.8 & 5.8 & 4.4 & 3.8 \\
\hline Araújo et al. (2014) & AP & $\mathrm{H}+\mathrm{Al}=62.08-14.394 \mathrm{SMP}+0.8263 \mathrm{pHSMP}{ }^{2}$ & 14.0 & 10.8 & 7.9 & 5.5 & 3.4 & 1.8 \\
\hline Almeida Júnior et al. (2015) & PB & $\mathrm{H}+\mathrm{Al}=57.108-13.338 \mathrm{SMP}+0.7637 \mathrm{pHSMP}{ }^{2}$ & 12.6 & 9.5 & 6.9 & 4.6 & 2.7 & 1.2 \\
\hline Present study - all soils & MT & $\mathrm{H}+\mathrm{Al}=53.105-26.54 \ln (\mathrm{pHSMP})$ & * & 10.4 & 7.9 & 5.6 & 3.4 & 1.5 \\
\hline Present study $<350 \mathrm{~g} \mathrm{~kg}^{-1}$ clay & MT & $\mathrm{H}+\mathrm{Al}=49.972-24.94 \ln (\mathrm{pHSMP})$ & * & 9.8 & 7.5 & 5.3 & 3.3 & 1.4 \\
\hline Present study $\geq 350 \mathrm{~g} \mathrm{~kg}^{-1}$ clay & MT & $\mathrm{H}+\mathrm{Al}=53.11-26.47 \ln (\mathrm{pHSMP})$ & * & 10.5 & 8.0 & 5.7 & 3.6 & 1.6 \\
\hline
\end{tabular}

†SP - São Paulo, MG - Minas Gerais, GO - Goiás, PR - Paraná, MS - Mato Grosso do Sul, RS/SC - Rio Grande do Sul, Santa Catarina, RO - Rondônia, PA - Pará, AP - Amapá, PB - Paraíba, PB - Pernambuco, MT - Mato Grosso; †† pH for equations in this study ranging from 5.00 to 7.38 .

The differences between the equations derived in this study and other equations used in other Brazilian states underline the importance of calibrating the SMP method to accurately estimate the $\mathrm{H}+\mathrm{Al}$ values for the main classes of soils cultivated in the state of Mato Grosso. This was more evident when using the estimated values of $\mathrm{H}+\mathrm{Al}$ for limestone recommendations, as different regression equations, compared to the equation in this study, commonly overestimated or underestimated the amount of limestone required for $\mathrm{pH}$ correction of different soils in the state of Mato Grosso (Table 3).

For example, by substituting $\mathrm{pH}_{\mathrm{SMP}}=5.28$ to estimate the potential acidity of a Red-Yellow Dystrophic Latosol (LVAd or Ferralsol, Oxisol) (Table 3) in the equation calibrated for Mato Grosso (Figure 2) and comparing the result with those from two equations used in the border states of Mato Grosso by Sousa et al. (1989) and Maeda et al. (1997) and the equation of Quaggio, Van Raij and Malavolta, (1985), calibrated for soils of São Paulo (which presents a different climate from Mato Grosso), we verified that although it is still widely used in laboratories of the west-central region of Brazil, the equation of Sousa et al. (1989) underestimated the amount of limestone by up to $0.64 \mathrm{Mg} \mathrm{ha}^{-1}(\mathrm{H}+\mathrm{Al}=$ $8.0041 \mathrm{cmol}_{\mathrm{c}} \mathrm{dm}^{-3}$ ), whereas that of Maeda et al. (1997) overestimated it by up to $1.97 \mathrm{Mg} \mathrm{ha}^{-1}(\mathrm{H}+\mathrm{Al}=11.9250$ $\mathrm{cmol} \mathrm{dm}^{-3}$ ) and that of Quaggio, Van Raij and Malavolta, (1985) overestimated it by up to $0.32 \mathrm{Mg} \mathrm{ha}^{-1}(\mathrm{H}+\mathrm{Al}$ $\left.=9.0264 \mathrm{cmol}_{\mathrm{c}} \mathrm{dm}^{-3}\right)$. The formula for calculating the liming requirement was $\mathrm{NC}\left(\right.$ ton $\left.\mathrm{ha}^{-1}\right)=[(\mathrm{V} 2-\mathrm{V} 1) \times$ $\mathrm{CTC} \times \mathrm{f}] / 100$, where $\mathrm{V} 2=60 \%, \mathrm{~V} 1=[(\mathrm{SB} / \mathrm{CTC})$ $\times 100], \mathrm{f}=1(100 / \mathrm{PRNT})$, and $\mathrm{SB}=0.4 \mathrm{cmol}_{\mathrm{c}} \mathrm{dm}^{-3}$. Thus, for this soil, the equation that best approximated the values obtained in the present study was that of Quaggio, Van Raij and Malavolta (1985). However, for sandy soils with a higher buffer $\mathrm{pH}$ (RQo; buffer $\mathrm{pH}=$ 6.28 ), the underestimation of limestone reached $1.00 \mathrm{Mg}$ $\mathrm{ha}^{-1}$, especially when using the equation of the present study, which separates the soils by clay content $(>350$ $\mathrm{g} \mathrm{kg}^{-1}$ clay) (Table 3 ).

Therefore, we conclude that preliminary analysis of the clay content in soil is important for minimizing error when estimating potential acidity (Table 3). This discussion is relevant in view of the 16 million hectares cultivated with grain and fibre crops in the state of Mato Grosso (Imea, 2017). Therefore, as the potential acidity in Mato Grosso is estimated mostly by the equations of Sousa et al. (1989) and Quaggio, Van Raij and Malavolta, (1985), which underestimate $\mathrm{H}+\mathrm{Al}$ for soils with a $\mathrm{pH}>5.43$, values typical of Mato Grosso, insufficient correction of soil acidity may occur because of a lower dose of lime applied to the soil. If soil acidity is not adequately corrected, according to Sousa and Lobato 
Table 3: Limestone addition recommendations for Mato Grosso state soils using the $\mathrm{H}+\mathrm{Al}$ values estimated by different regression equations (V2 $=60 \%$, PRNT $=100 \%$ ).

\begin{tabular}{|c|c|c|c|c|c|c|c|c|c|c|c|c|}
\hline \multirow{2}{*}{ Source } & \multirow{2}{*}{ State } & \multicolumn{11}{|c|}{ Soil types ${ }^{(1)}$} \\
\hline & & LVAd & GXd & CXd & CXd & CXd & PVAd & FTXd & RQo & PVAd & LVAd & LVd \\
\hline & & \multicolumn{11}{|c|}{ 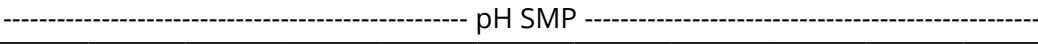 } \\
\hline & & 5.28 & 5.43 & 5.74 & 6.03 & 6.08 & 6.17 & 6.22 & 6.28 & 6.28 & 6.91 & 6.91 \\
\hline & & \multicolumn{11}{|c|}{ 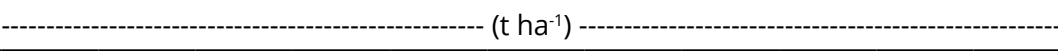 } \\
\hline $\begin{array}{l}\text { Quaggio, Van Raij and Malavolta, } \\
\text { (1985) }\end{array}$ & SP & 5.25 & 3.17 & 4.06 & 0.00 & 0.86 & 0.00 & 1.63 & 0.74 & 0.62 & 0.00 & 0.00 \\
\hline Gama et al., (2013) & MG & 5.21 & 3.11 & 3.96 & 0.00 & 0.75 & 0.00 & 1.51 & 0.62 & 0.50 & 0.00 & 0.00 \\
\hline Sousa et al. (1989) & GO & 4.64 & 2.64 & 3.67 & 0.00 & 0.57 & 0.00 & 1.38 & 0.50 & 0.38 & 0.00 & 0.00 \\
\hline $\begin{array}{l}\text { Pavan, Oliveira and Miyazawa, } \\
\text { (1996) }\end{array}$ & PR & 4.94 & 3.11 & 4.35 & 0.19 & 1.34 & 0.19 & 2.15 & 1.27 & 1.15 & 0.30 & 0.25 \\
\hline Maeda et al. (1997) & MS & 6.98 & 4.66 & 5.12 & 0.50 & 1.59 & 0.34 & 2.26 & 1.32 & 1.20 & 0.44 & 0.00 \\
\hline Escosteguy and Bissani (1999) & $\mathrm{RS} / \mathrm{SC}$ & 3.96 & 2.14 & 3.45 & 0.00 & 0.54 & 0.00 & 1.39 & 0.53 & 0.40 & 0.00 & 0.00 \\
\hline Moline et al. (2011) & RO & 2.47 & 0.99 & 2.88 & 0.00 & 0.43 & 0.00 & 1.45 & 0.65 & 0.52 & 0.00 & 0.37 \\
\hline Gama et al. (2013) & PA & 5.21 & 3.44 & 4.78 & 0.67 & 1.84 & 0.71 & 2.68 & 1.81 & 1.69 & 0.81 & 1.06 \\
\hline Araújo et al. (2014) & AP & 5.31 & 3.51 & 4.74 & 0.47 & 1.60 & 0.40 & 2.33 & 1.41 & 1.29 & 0.50 & 0.00 \\
\hline Almeida Júnior et al. (2015) & PB & 4.63 & 2.86 & 4.15 & 0.00 & 1.08 & 0.00 & 1.84 & 0.93 & 0.81 & 0.00 & 0.00 \\
\hline Present study - all soils & MT & 5.21 & 3.46 & 3.74 & 0.52 & 1.65 & 0.45 & 2.38 & 1.45 & 1.33 & 0.55 & 0.00 \\
\hline Present study $<350 \mathrm{~g} \mathrm{~kg}^{-1}$ clay & MT & 4.93 & 3.21 & 4.56 & 0.47 & 1.51 & 0.32 & 2.25 & 1.34 & 1.22 & 0.42 & 0.00 \\
\hline Present study $\geq 350 \mathrm{~g} \mathrm{~kg}^{-1}$ clay & MT & 5.28 & 3.54 & 4.84 & 0.60 & 1.73 & 0.53 & 2.46 & 1.53 & 1.41 & 0.63 & 0.00 \\
\hline
\end{tabular}

(1) LVAd - Dystrophic Red-Yellow Latosol; GXd - Dystrophic Haplic Gleysol; CXd - Dystrophic Haplic Cambisol; PVAd - Dystrophic Red-Yellow Argisol; FTXd - Dystrophic Haplic Plinthosol; RQo - Ortic Quartzarenic Neosol; LVd - Dystrophic Red Latosol. Note: The soils were classified according to the Brazilian Soil Classification System - SiBCS (Santos et al., 2013).

(2004), the desired base saturation will be not reached for proper plant development. This may explain why the saturation level by desired bases has not been reached in practice in soybean production areas (Fundação MT, 2017). Then, considering that according to the IMEA (2017), up to $20 \%$ of grain production cost is invested in the acquisition of $\mathrm{pH}$-corrective materials and fertilizers, the use of an equation other than that found in the present study, that is, an equation including SMB $\mathrm{pH}$ or SMP $\mathrm{pH}$ (Figure 2), might limit the profitability of agricultural activity in Mato Grosso.

\section{CONCLUSIONS}

Overestimation or underestimation of liming may occur if equations that are not calibrated for a given region are used to estimate potential acidity. The SMP and SMB methods for $\mathrm{pH}$ determination were found to be equivalent and provide better estimates of potential acidity $(\mathrm{H}+$ $\mathrm{Al})$ than the Sikora buffer method and thus to be better replacements for the standard method of extraction used in soil analysis laboratories in the state of Mato Grosso. However, as the SMP method uses toxic reagents, it is better to use the SMB method because it has the additional advantage of not generating pollutant residues. Thus, SMB can be used to estimate the potential acidity $(\mathrm{H}+\mathrm{Al})$ of soils in the state of Mato Grosso using the equation $\mathrm{H}+$ $\mathrm{Al}\left(\mathrm{cm}_{\mathrm{c}}^{3} \mathrm{dm}^{-3}\right)=51.189-25.70 \ln \left(\mathrm{pH}_{\mathrm{SMB}}\right)\left(\mathrm{R}^{2}=0.88, \mathrm{P}<\right.$ $0.0001)$.

\section{ACKNOWLEDGEMENTS}

We thank APROSOJA-MT (Soy Producers Association of the State of Mato Grosso -Brazil) and FAPEMAT (Foundation for Research Support of the State of Mato Grosso - Brazil) for the financial support of this research. We thank CAPES (Coordination of Superior Level Staff Improvement - Brazil) for providing the research grant to the first author. We thank $\mathrm{CNPq}$ (National Council for Scientific and Technological Development 
- Brazil) for providing the research grant to the second author. We thank EMBRAPA (The Brazilian Agricultural Research Corporation - Brazil) for intellectual and laboratory support. We thank FMT (Foundation for Agricultural Research Support of the State of Mato Grosso - Brazil) and EMPAER-MT (Rural Extension, Assistance and Research Company of Mato Grosso - Brazil) for intellectual support.

\section{REFERENCES}

ALMEIDAJUNIOR, A. B.; NASCIMENTO, C. W. A.; BARROS, F. M. R. Potential acidity estimated by the $\mathrm{pH}$ SMP method in soils of the State of Paraíba. Revista Brasileira de Ciência do Solo, 39(3):767-773, 2015.

ALVARES, C. A. et al. Köppen's climate classification map for Brazil. Meteorologische Zeitschrift, 22(6):711-728, 2013.

ARAÚJO, D. M. F. et al. Potential acidity of soils in the Amapá State estimated by the potentiometric SMP method. Acta Iguazu, 3(3):57-65, 2014.

ESCOSTEGUY, P. A.; BISSANI, C. A. Estimation of $\mathrm{H}+\mathrm{Al}$ by SMP $\mathrm{pH}$ in soils of the State of Rio Grande do Sul and Santa Catarina. Revista Brasileira de Ciência do Solo, 23(1):175-179, 1999.

FUNDAÇÃO MT. Boletim de pesquisa de soja 2017/2018. 2017. Available in: <https://www.fundacaomt.com.br/ boletim-de-pesquisa>. Access in: October, 6, 2019.

GAMA, M. A. P. et al. Potential acidity estimated by SMP pH in soils of the state of Pará. Revista Brasileira de Ciência do Solo, 37(1):199-203, 2013.

INSTITUTO MATOGROSSENSE DE ECONOMIA AGRÍCOLA - IMEA. Agronegócio em Mato Grosso 2016. 2017. Available in: <http://www.imea.com.br/imea-site/>. Access in: October, 6, 2019.

LARSON, R.; FARBER, B. Estatística aplicada. Pearson Prentice Hall, São Paulo, 2010. 640p.

MAEDA, S. et al. Estimativa da acidez potencial, pelo método do SMP pH, em solos do Mato Grosso do Sul. EMBRAPA, Dourados, Boletim de Pesquisa, n.3, 1997. 25p.

MAIA, S. M. F. et al. Effect of grassland management on soil carbon sequestration in Rondônia and Mato Grosso states, Brazil. Geoderma, 49(1):84-89, 2009.
MOLINE, E. F. V. et al. Estimated value of $H+A L$ by orrelation with soil ph in SMP Rondônia. Enciclopédia Biosfera, 7(12):1-6, 2011.

MOREIRA, A. et al. Potential acidity by pH SMP method in Amazonas State, Brazil. Pesquisa Agropecuária Brasileira, 38(1):89-92, 2004.

MOREIRA, M. L. C.; VASCONCELOS, T. N. N. Mato Grosso: Solos e paisagens. Entrelinhas, Cuiabá, 2007. 272p.

PAVAN, M. A.; OLIVEIRA, E. L.; MIYAZAWA, M. Indirect determination of soil extractable acidity $(H+A l)$ by potentiometry with the SMP buffer solution. Brazilian Archives of Biology and Technology, 39(1):307-312, 1996.

PEREIRA, M. G. et al. Estimation of potential acidity by ph SMP method in soils from Rio de Janeiro state, Brazil. Revista Brasileira de Ciência do Solo, 22(1):159-162, 1998.

PREDEBON, R. et al. Accuracy of methods to estimate potential acidity and lime requirement in soils of west region of Santa Catarina. Ciência Rural, 48(4):1-4, 2018.

QUAGGIO, J. A.; VAN RAIJ, B.; MALAVOLTA, E. Alternative use of the SMP-buffer solution to determine lime requirement of soils. Communications in Soil Science and Plant Analysis, 16(3):245-260, 1985.

RAMOS, F. T. et al. Soil organic matter doubles the cation exchange capacity of tropical soil under no-till farming in Brazil. Journal of The Science of Food and Agriculture, 98(9):3595-3602, 2018.

SANTANNA, M. A. et al. Evaluation of sikora instead of SMP buffer to estimate the potential acidity of brazilian soils. Revista Brasileira de Ciência do Solo, 35(5):1707-1712, 2011.

SANTOS, H. G. et al. Sistema Brasileira de Classificação do solo. $3^{a}$ edição. Embrapa Solos, Brasília, 2013. 353p.

SHOEMAKER, H. E.; MCLEAN, E. O.; PRATT, P. F. Buffer methods for determining lime requirement of soil with appreciable amounts or extractable aluminium. Soil Science Society of America Journal, 25(4):274-277, 1961.

SIKORA, F. J. A buffer that mimics the SMP buffer for determining lime requirement of soil. Soil Science Society of America Journal, 70(2):474-486, 2006. 
SILVA, E. B.; COSTA, H. O. O.; FARNEZI, M. M. Potential acidity estimated by $\mathrm{pH}$ SMP method in soils of the Jequitinhonha Valley, Minas Gerais state, Brazil. Revista Brasileira de Ciência do Solo, 30(4):751-757, 2006.

SILVA, E. B. et al. Comparação de métodos para estimar a acidez potencial mediante determinação do $\mathrm{pH}$ SMP em Organossolos da Serra do Espinhaço Meridiona. Revista Brasileira de Ciência do Solo, 32(5):20072013, 2008.

SOUSA, D. M. G.; LOBATO, E. Cerrado: Correção e adubação. Brasília, DF: Embrapa Informação Tecnológica; Planaltina, DF: Embrapa Cerrados, 2004. 416p.
SOUSA, D. M. G. et al. Methods for determining liming needs in cerrado soils. Revista Brasileira de Ciência do Solo, 13(2):193-198, 1989.

STEINER, F. et al. Acidez potencial estimada pelo método do $\mathrm{pH}$ SMP em solos do Estado do Paraná. Cultivando o Saber, 2(4):33-41, 2009.

TEIXEIRA, P. C. et al. Manual de Métodos de Análise de Solo. $3^{a}$ edição. Brasília, Embrapa, 2017. 573p.

TOLEDO, J. A. et al. Santa Maria buffer as an alternative to the SMP buffer to measure potential acidity of acid soils. Revista Brasileira de Ciência do Solo, 36(2):427-435, 2012. 